\title{
Professional development of a teacher on the Yandex. Textbook platform as a necessary condition for improving the quality of education in a modern school
}

\author{
I.G. Kalinina ${ }^{1 *}$, I.V. Enova ${ }^{2}$, and N.M. Tolkova ${ }^{3}$ \\ ${ }^{1}$ State Educational Institution of Higher Education of the Moscow Region State Humanitarian and \\ Technological University of Orekhovo-Zuevo, Orekhovo-Zuevo, Russia \\ ${ }^{2}$ State Educational Institution of Higher Education of the Moscow Region State Humanitarian and \\ Technological University of Orekhovo-Zuevo, Orekhovo-Zuevo, Russia \\ ${ }^{3}$ State Educational Institution of Higher Education of the Moscow Region State Humanitarian and \\ Technological University of Orekhovo-Zuevo, Orekhovo-Zuevo, Russia
}

\begin{abstract}
The study reveals the current topic of digitalization of modern education. Its importance is due to the transition to a new level of teaching in educational institutions. The study examines the development of professional pedagogical competencies as a fundamental condition that directly affects the quality of the educational process.
\end{abstract}

\section{A problem statement}

Digitalization of modern higher education, on the one hand, is a reality of modern times, on the other hand, it is a challenge to the entire education system. The movement towards digitalization of higher education has deep goals and meaning, that is, it is not only a national decision and is not an end in itself.

In 1999, a unified system of European higher education was created, which was recognized in more than 29 states that signed the Bologna Declaration, including Russia. The main mission of the Bologna Process is to improve the quality, relevance of learning and teaching. This process has been going on in Russia for twenty years. Modern higher education plays an important role in the development of society, economy, prosperity in Russia, as well as in European countries.

At the present stage, digital technologies permeate almost all spheres of society, and it is digitalization that can change the approaches of higher educational institutions to teaching people at different stages of life. The task of higher educational institutions is to prepare students and support the teaching staff in the development of the educational environment in an electronic environment. Our main goal is to adapt educational systems for the full and informed use of blended and digital education.

\footnotetext{
* Corresponding author: ipcs-profped@yandex.ru
} 


\subsection{The objective of the work}

During the research, we applied theoretical research methods such as analysis, synthesis, generalization, classification, and forecasting). The research is based on the provisions on distance learning (research by A.A. Andreev, I.A. Soldatkin, etc.), the study of patterns and ways of distance and electronic education (research by D. Keegan, R. Delling, A. Wedemeer, M. Allen, etc.) [10, 11].

\section{Materials and the results of the research}

In modern society, a digital transformation of higher education institutions is taking place. This is due to the need to move to a digital environment from an analog one. In this connection, there is a need to revise the entire structure of the educational process. But the problem is that not all higher education institutions are ready for new conditions and rapid changes.

Analysis of modern pedagogical research on the problem of digitalization of higher education allows us to conclude that it is necessary to adapt our learning system to use electronic resources for the diversity and flexibility of types of distance continuous learning and the creation of open e-learning systems.

Various digital resources already exist in Russia, one of the first platforms was Open Education. The platform offers online courses in disciplines studied in higher education institutions. This platform was created by the Association "National Platform for Open Education" by the largest universities in our country. The courses located on the platform can be taken free of charge and without reference to education, in addition, according to the results of the course, it is possible to obtain a certificate. All courses on the national platform are created in accordance with federal state educational standards, but our analysis showed that the catalog of available courses, from the point of view of those applicable in our educational institution - the State Educational Institution of Higher Education of the Moscow Region State Humanitarian and Technological University, is very limited. But we are not standing still and are looking for various available digital platforms that will be possible to integrate into the educational process.

The digitalization of the educational process plays a huge role in the development of all education and serves as the foundation for the transition to a higher level and is aimed at training universal specialists needed in the labor market. The requirements for all participants in the educational process have changed, it is necessary to fully use these resources, to fruitfully interact with each other. It is necessary to adapt to the new conditions of modern society.

The modern education system implements the digital transformation of society by involving all participants in the educational process in information interaction. Digital education tools help to quickly and efficiently solve the problems of classical education: types of training, teacher choice, etc. Society has reached a high level of educational technologies.

The problems of distance, interactive, and digital education have been studied by a wide range of foreign and domestic scientists Afanasyev Yu.N., Akhayan A.A., Khutorskoy A.V., Chernobay E.V., Delling R.M. (Germany), Wedemeyer Ch.A. (USA), Murom M.J., and others.

Delling R.M. considered distance education as a system in which a choice of various materials necessary for teaching is possible, in addition, it is possible to observe and help the student through various means of communication. Delling created the foundations of the theory of autonomy and independence of distance learning. The central position in the theory of R.M. Delling takes the concept of two-way communication with feedback. 
M.J. Moore supported the point of view of R.M. Delling, his proposed classification of educational distance learning programs was characterized by two definitions: "distance" and "autonomy".

A. Bates, B. Holmberg, D. Stewart are the founding fathers of the theory of interaction and communication. The principle of two-way communication is the main feature of the modern distance learning system.

C. Wedemeyer's concept is based on the possibility of self-education. He argued that "independent learning" should take place at the individual pace of the learner. The teacher and the student must each perform their function separately from each other, maintaining interaction in separate ways. Wedemeyer believed that in order to overcome the space-time barrier in education, it is important to separate the process of teaching and learning. Features of the distance education system proposed by Wedemeyer:

- territorial division of the teacher and the student;

- training is carried out using various means of communication;

- training is strictly individual;

- the student himself is responsible for his own achievements and successes;

- the student is in a comfortable environment.

Distance models of foreign researchers involve the development of systems of pedagogical technologies through which it is possible to implement their main ideas.

The distance learning process in Russia begins in the nineties. A lot of work begins to be carried out at the Russian Academy of Education.

Under the leadership of E. S. Polat, in the distance learning laboratory, developed theoretical foundations and practice-oriented courses.

A.V. Khutorskiy explores the problems of heuristic distance learning.

A large number of fruitful ideas on the organization and practical application of using distance technologies can be found in the projects of the electronic university of the Moscow Institute of Electronics and Mathematics (under the leadership of S.M. Moiseev), the electronic faculty of advanced training of the Moscow State University (under the leadership of V.A. Sadovnichev).

Thus, having reviewed the studies on distance, e-learning, we can say that despite the unstable socio-economic situation in Russia, the e-education system is developing both in higher education and in the retraining system for teaching staff.

Speaking about digitalization of modern education, we mean:

1. Direct application of digital technologies in teaching.

2. Application of digital technologies to assess the development of the program.

3 . In the management system of an educational organization.

Higher education does not stand still and is actively transforming towards digitalization of the educational process.

Many years of experience suggests that any innovations, reforms in the education system cannot give positive results if the teacher is not a professional in this competence. In this connection, the requirements for a modern teacher have changed dramatically, the teacher must now constantly develop and improve himself in the professional field.

The modern world is changeable and dynamic, it requires constant self-development and improvement from the individual. Education is undergoing the same changes, ten years ago, having received a higher education, one could feel free and comfortable, at the present moment the situation has changed and the knowledge gained today, tomorrow may no longer be relevant, i.e. the process of acquiring knowledge and its obsolescence occurs almost simultaneously. In this situation, the teacher's activity becomes more complicated, and the teacher will be a professional in his field only if he develops his whole life. In such conditions, the work of a teacher becomes much more complicated, and the only way out of this situation. 
The intensification of education leads to a constant change in the content and volume of acquired knowledge; in addition, educational technologies are also changing. In this connection, a modern teacher should be aware of the latest innovations and innovations, and actively apply in their activities.

In our research, we will rely on two relevant concepts - "professionalism" and "competence" [2, 6, 8].

Professionalism is a special human trait to constantly, efficiently and reliably perform various activities in any conditions. This concept reflects the whole essence of a person's mastery of the psychological structure of professional activity, which corresponds to the standards and objective requirements existing in society [3].

The concept of "competence" should be distinguished from professionalism. Competence is included in professionalism as a basic element, but these concepts are not identical.

Competence is the knowledge and experience necessary for effective activity in a given subject area. Competence is the quality of a person who has knowledge in any field and whose opinion is authoritative $[4,5]$.

In terms of its scope, the concept of "professionalism" is broader, since it includes a special outlook on life (worldview), and a special system of attitudes toward oneself, toward one's work, toward other people. This is also a special kind of motivation. In short, competence is one of the main, but not the only, component of professionalism.

Thus, if we call a teacher professionally competent, it means that he carries out his activities at a sufficiently high level and demonstrates stable positive results. The basis of his activities is primarily formed by the formed pedagogical competencies: subject, methodological, psychological and pedagogical, differential and psychological.

The quality of modern education directly depends on the professional training of modern teachers. The demands made today by society and the social order of parents and future employers to a modern graduate are very high. The main characteristics that a graduate of a modern school must meet are spelled out in the new federal educational standard [9]. Here are some of them as an example.

- The current graduate is a creative and critical person who realizes the value of education and science, labor and creativity for a person and society:

- owning the basics of scientific methods of cognition of the surrounding world;

- $\quad$ motivated for creativity and innovation;

- ready for cooperation, able to carry out educational and research, project and information and educational activities;

- $\quad$ respecting the opinion of other people, able to conduct a constructive dialogue, achieve mutual understanding and successfully interact;

- consciously fulfilling and promoting the rules of a healthy, safe and environmentally sound lifestyle;

- $\quad$ prepared for a conscious choice of profession, understanding the importance of professional activity for a person and society;

- $\quad$ motivated for education and self-education throughout his life [7].

The world of professions is not standing still today either. Not only the types of professional activity already known to us are constantly filled with new content, but absolutely new types of professions appear [7].

According to the calculations of specialists from the Ministry of Labor and Social Development, 57 professions will disappear by 2030 and 186 new ones will appear, such as a designer of new metals, an eco-auditor, a meteo-energy specialist, a molecular nutritionist, an IT physician, an informist, a bioethics, a personal safety designer, an architect of living systems, a clinical bioinformatist, IT geneticist [2]. 
In such conditions, today's school graduate must be prepared for the fact that he will have to constantly retrain throughout his life. And the development of new professions without highly qualified teaching staff will be impossible.

The teaching profession has its own distinctive feature: the personality of the teacher is a powerful tool, the more perfect this tool, the more successful the result. It is in the teaching profession that personal growth is an indispensable condition for achieving professionalism.

What mechanisms can organize a teacher's activities aimed at developing professional pedagogical competencies?

First of all, it is a well-built system of methodological work in an educational institution. At the same time, the initial identification of the level of the teacher's professional competence through diagnostics, testing, etc. will determine the ways to improve the teacher's professional skills. From the first minute of the appearance of a young teacher at school, it is necessary to provide for the help of teachers-mentors at the stages of developing training sessions, individual consultations, attending training sessions, assistance in building correct relationships with students, parents and colleagues. Next, it is necessary to determine the very mechanisms for the development of teacher professionalism. Within the framework of the methodological system of the educational institution and the municipality, various events are provided that allow teachers to study advanced pedagogical experience, present their developments, and attend training sessions. In addition, as a rule, school teachers are active participants in professional network communities. Thematic pedagogical councils, conferences, round tables, master classes, workshops, subject events, refresher courses organized and conducted at various venues of the city stimulate the growth of teachers in the profession [5].

The method of organizing the work of problem-creative groups in the school, which includes all the teaching staff of the school, has proven itself quite well. Throughout the academic year, teachers work on the chosen topic. Topics can be of very different orientations, for example: "Semantic reading: techniques and methods of work in classrooms", "Problems of implementing the Federal State Educational Standard", "Implementation of the technology of integrated lessons as one of the means of forming UUD among students", "Science for the layman or practical application scientific knowledge "," A systematic approach to work with gifted children"," The use of distance technologies in the educational process. " The problem-creative group finishes its work by presenting a report at the pedagogical council.

Participation in professional competitions, for example, "Teacher of the Year", also contributes to the improvement of the level of methodological training of a teacher.

The system of material incentives for the professional success of teaching staff also plays an important role here.

One of the most effective mechanisms for improving the professional competence of a teacher is the teacher's self-education. Today, the most diverse forms of organizing the teacher's self-education are used: obtaining a higher education or a second specialty, professional retraining, continuous professional development, work on an individual educational trajectory.

If the teacher is constantly in search of new knowledge, is engaged in self-development, then the results will certainly show themselves and have a positive effect on the educational process.

But any activity becomes meaningless if as a result there are no achievements or no product of the activity. Each teacher, in terms of self-education, necessarily prescribes the results that he must achieve within a certain period. For example, presentations at events of various levels, the development of didactic materials, teaching aids, etc. 
It is difficult to overestimate the role of self-education in the development of a teacher's pedagogical competence. This is, first of all, improving the quality of the educational process, readiness for creativity, professional and career growth, creating the image of a modern teacher, teacher-innovator, teacher-master, mentor, compliance of the teacher with the requirements of society and the state.

In the digital age, an important aspect in the professional development of a teacher has become the integration of IT competencies into the trajectory of a teacher's professional development. In order to integrate elements of digitalization into the educational process, Yandex launched a professional development program for teachers. The goal of the "I am a Teacher" program is to help them master the teaching skills and practices necessary for teaching children in the modern world. More than 25 training institutes and universities are partners of the program.

"With the development of technology, the value of live communication and learning is only growing. Today's teachers are versatile people who can inspire children to get new knowledge by their own example," says the Yandex strategy Director.Textbook Natalia Chebotar.

On the "I am a Teacher" website, teachers will get free access to courses, online services, webinars, and expert articles.

Teachers spend a lot of time and energy on self-education. Regular refresher courses, intensive courses, the search for materials for the lesson - all this is part of the teacher's work. How to make the self-study process as efficient as possible and not waste time on something that is definitely not useful?

\section{Define your needs}

Start with diagnostics. Surely, you already know what you want to learn, but analyze the ratio of "want" and "need". For example, you have long wanted to learn the flipped class technique. Is it just interest? Or maybe your colleagues began to conduct lessons in a new way on a massive scale, so you don't want to get out of the team? Or is it that you are missing new teaching methods? Ask yourself the question: "Is this really something that will come in handy in my work?" If the answer is yes, you are on the right track.

2. State your goal

You have identified your problem points and needs. The next step is to formulate the goal and objectives of independent work. For example, you want to learn how to conduct online lessons. This is your goal. Tasks are individual steps that will help you achieve it. With their help, you can motivate yourself and track your progress. Set a task for the week prepare your first online lesson. Then divide the task into smaller tasks: choose a platform for an online lesson, write a lesson plan. Celebrate each task you complete - this way you will get satisfaction and feel like you are moving forward. At the end of each day, praise yourself for small accomplishments, and at the end of the week, summarize the totals.

\section{Select a shape}

Each form of teacher self-education has its own advantages and disadvantages. Consider these when choosing the learning model that is right for you. Courses at advanced training institutes provide support from professionals and the experience of colleagues, but take place during the academic period and take up a lot of time. Distance courses are suitable if there is no time to travel somewhere. You can study online at a convenient time, but highquality distance courses are often paid for and require a high level of knowledge of computer technology. An individual form of self-education seems to be the most accessible, but you must be highly motivated and able to plan your time, since you will have to study a large number of materials on your own and choose what is really useful.

\section{Test new knowledge in practice}

Self-education of a teacher is impossible without practice. All the theoretical knowledge gained must be applied in real conditions. It all depends on your goal and the chosen topic. 
Give some lessons using new teaching methods and forms. Prepare a work program or didactic materials. Organize an extracurricular activity or workshop for your colleagues.

Perhaps something will not work the first time. Dont be upset. Keep working to correct your work.

5. Prepare a report

At the end of the work, analyze the whole process, evaluate your results, draw conclusions, what happened and what difficulties arose. Be sure to praise yourself, because you have spent a lot of time and effort on self-education. Want to get recognized for your work? Share your experience with colleagues and make recommendations. They will appreciate your services.

The forms of reports can be different, for example, a report, an open lesson, a presentation to the teaching staff.

\section{Conclusions}

Thus, digitalization of higher education is a multifaceted process that covers all spheres of society. A process subject to understanding, development, and active implementation in the practical activities of educational organizations. In addition, the development of professional pedagogical competencies is a fundamental condition that directly affects the quality of the educational process. A modern teacher is a person who is able to take an interest in everything that surrounds him, he is a professional whose skill is determined by the level of his professionalism and self-development. The modern teacher must strive for success. And a successful teacher will certainly bring up a successful student.

\section{References}

1. N.A. Asanova, Basic competences of a modern teacher, Electronic resource, Access mode: https://portalpedagoga.ru/servisy/publik/publ?id=7274

2. Atlas of new professions, Electronic resource, Access mode: http://atlas100.ru/catalog/

3. S.A. Druzhilov, Generalized (integral) approach to ensuring the formation of human professionalism, Psychological research: electron. scientific magazine, 1 (21) (2012) Access mode: http://psystudy.ru/index.php/num/2012n1-21/621-druzhilov21.html

4. I.A. Zimnyaya, Key competencies as an effective-target basis of a competence-based approach in education, p. 38 (Moscow, 2004)

5. I.V. Robert, S.V. Panyukova, A.A. Kuznetsov, et al., Information and communication technologies in education: educational method. manual for pedagogical universities (Moscow: Publishing house IIO RAO, 2006)

6. Competence. Dictionaries and encyclopedias on the Academician, Electronic resource, Access mode: https://dic.academic.ru/dic.nsf/ruwiki/1526590

7. G.A. Mavlyugova, Digitalization in a modern higher educational institution, Economic security and quality, 3 (32) 5-7 (2018)

8. G.M. Sevumyan, Pedagogical competence of a modern teacher. Report, Electronic resource, Access mode: https://урок.pф/library/doklad_pedagogicheskie_kompetentcii_sovremennogo_uch_1 22822.html

9. Federal state educational standards, FSES of secondary general education, Electronic resource, Access mode: https://fgos.ru 
10. S. Rizvi, S. Ghani, Prediction of higher education engagement MOOCs; stochastic approach, Presented at the international annual research conference of the Society for Research in Higher Education (SRHE-16) (Newport, UK, 2016)

11. S. Sergis, D.G. Sampson, L. Pelliccione. Curriculum Design for MOOCs: Design Considerations for Large-Scale Learning with Technology, 39-71 (In the field of open education: from proposals to MOOCs Berlin: Springer, 2017) 